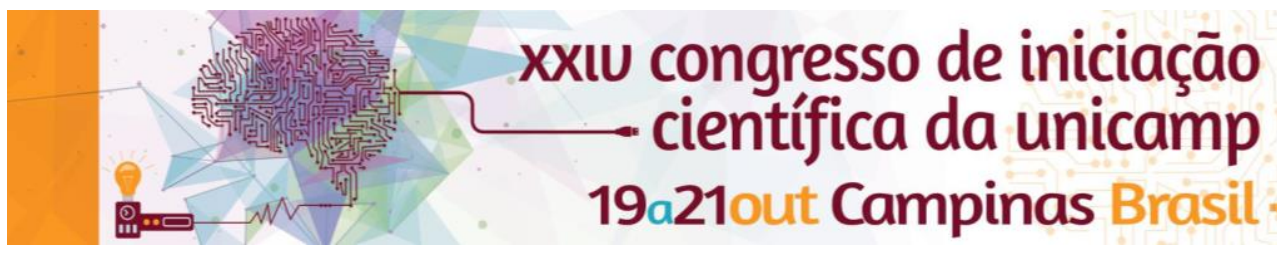

\title{
As cores no processo de comunicação visual dos catálogos da Natura
}

\author{
Patrícia Bento Rosa*, Edson do Prado Pfützenreuter.
}

\section{Resumo}

A Natura é uma empresa brasileira com destaque nacional e global nos quesitos econômico (mercado) e ético, no segmento de Saúde e Beleza. Sendo uma empresa de grande porte, necessita de eficientes estratégias de comunicação com seu público-alvo para transmitir os seus ideais e conquistar consumidores. Pensando no catálogo como o objeto que conecta o público-alvo com os produtos e percebendo os elementos visuais nele presente como chave para a comunicação da marca, o objetivo deste projeto é estudar as cores, que são um dos mais estimulantes e influentes elementos visuais, e verificar como elas são utilizadas no catálogo para transmitir mensagens, como o posicionamento da marca e o estímulo à compra.

\section{Palavras-chave: \\ Cor, comunicação, Natura.}

\section{Introdução}

A Natura é uma empresa brasileira que atua no setor de cosméticos, perfumaria e higiene pessoal e se destaca pela ética e preocupações sociocultural e ambiental. O guia para todas as ações estão apontadas em sua "essência"1, aonde são expostas suas crenças e razão de ser, entre elas a valorização das relações humanas, da brasilidade e da beleza natural, a sustentabilidade e a inovação. Todos esses valores permeiam a comunicação visual da marca na qual um dos elementos fundamentais é a cor, incluindo os catálogos, uma espécie de vitrine dos seus produtos. As cores carregam cargas simbólicas relacionadas a experiências pessoais e ao repertório cultural. Esta pesquisa pretende analisar como a Natura utiliza as cores para estimular a venda e transmitir suas crenças. $O$ estudo das cores é interdisciplinar e adentra diferentes áreas do conhecimento, abrangendo questões químicas como composição dos pigmentos, os estudos da física e da luz, questões fisiológicas no nosso aparelho visual, questões psicológicas de interpretação e assimilação, questões relativas à estética $\mathrm{e}$ à associações simbólicas.

\section{Resultados e Discussão}

A análise foi desenvolvida com base em sete catálogos, sendo dois deles de 2015 e os demais de 2016. A importância da utilização das cores é percebida em diversos momentos, como:

- construção da identidade visual de cada marca;

- valorização e visibilidade aos produtos comercializados;

- delimitação do público-alvo (especificação de gênero, idade, estilo de vida, etc.);

- diferenciação dos preços dos produtos;

- destaque de informações importantes;

- organização visual do catálogo;

- promoção de interesse pela compra;

- construção da identidade da marca-mãe Natura.

Assim, as cores dão coerência e unificam a estratégia de comunicação da empresa. Para compreender os diferentes aspectos da cor foram utilizados os autores Farina, Perez e Bastos ${ }^{2}$, Guimarães ${ }^{3}$, Barros ${ }^{4}$ e Pedrosa ${ }^{5}$.

\section{Conclusões}

Este estudo permitiu concluir que, no caso da Natura, as cores são capazes de transmitir mensagens, valores e crenças, organizar informações, criar identificação com o público-alvo, despertar desejos nos consumidores, estimular a compra e conferir coerência e identidade à marca.

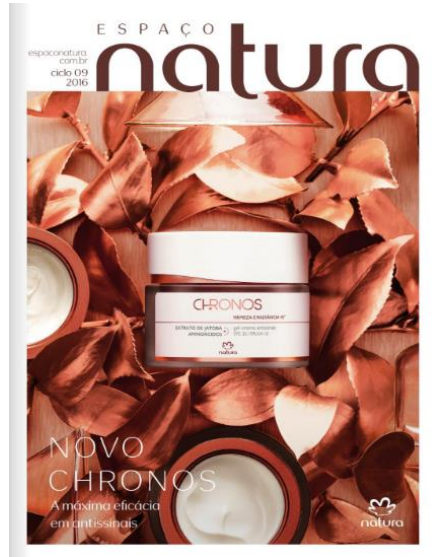

Figuras 1 e 2. Capas dos Ciclos 7 e 9 de 2016, respectivamente.

\section{Agradecimentos}

Agradeço à Universidade Estadual de Campinas e ao PIBIC pela oportunidade de realizar uma Pesquisa de Iniciação Científica, bem como os direcionamentos do meu orientador Prof. Dr. Edson Pfützenreuter e, ainda, às pessoas que me disponibilizaram catálogos e outros auxílios importantes para a realização desta pesquisa.

1NATURA. Essência. Disponível em: http://www.natura.com.br/anatura/sobre-a-natura/essencia. Acesso em: 28 de Jun. 2016.

2FARINA, M.; PEREZ, C.; BASTOS, D. Psicodinâmica das Cores em Comunicação. São Paulo: Blucher, 2011.173 p.

${ }^{3}$ GUIMARÃES, L. A cor como informação: a construção biofísica, lingüística e cultural da simbologia das cores. São Paulo: Ed. Annablume, 2004. 148 p.

${ }^{4}$ BARROS, L. R. M. A Cor no Processo Criativo: um estudo sobre a Bauhaus e teoria de Goethe. São Paulo: Ed. SENAC São Paulo, 2011. 336 p.

${ }^{5}$ PEDROSA, I. Da cor à cor inexistente. São Paulo: Ed. SENAC São Paulo, 2009, 256 p.

Link para o texto completo: https://goo.gl/XiPA9s 